\title{
Enhancing the performance of a wastewater treatment plant processing wheat starch factory tailings
}

\author{
E. F. Pidgeon \& J. N. Ness \\ Griffith School of Engineering, Griffith University, Australia
}

\begin{abstract}
The performance of a waste water treatment plant (WWTP) at a wheat starch factory (average flour throughput of $59 \mathrm{t} /$ day) is reported in this paper. Most factory-generated wastestreams were processed through the onsite WWTP prior to being discharged to a municipal wastewater treatment facility for further treatment. One stream was trucked off-site as 'liquid fertiliser'. Over the two-year monitoring period, the onsite WWTP discharged an average of $430 \mathrm{~kL}$ of wastewater per day (range 323-3,264, standard deviation 198) with an average suspended solids (SS) concentration of 2,500 mg/L (range 610-11,700, standard deviation 1,568) and an average $\mathrm{BOD}_{5}$ of $1,950 \mathrm{mg} / \mathrm{L}$ (range 140-13,000, standard deviation 1,855). Impacts to the WWTP as a result of water usage and wastewater generation practices within the manufacturing plant were investigated. The operation, effectiveness and maintenance of the system were assessed in terms of how water usage and practices within the starch recovery process affected effluent treatment performance. By-products of the treatment process included beneficial and non-beneficial outputs. For example, methane generated in the anaerobic digester was utilised in the boilers and offset the purchase of natural gas costs while excess anaerobic sludge posed a disposal problem, as there was no local market for this material. Performance inhibitors were identified during the study, as well as the consequences of failure of the anaerobic digester. Recommendations, based on theoretical background and practical experience are provided for enhancing this kind of treatment system and for reducing overall water usage in the starch factory.
\end{abstract}

Keywords: wheat starch, wastewater treatment, water usage, anaerobic treatment. 


\section{Introduction}

Traditionally, industrial processes were designed in the absence of consideration to wastes produced or the potential environmental impact that they may cause Unnikrishnan and Hegde [1]. As legislation was established and compliance issues arose, the wastewater treatment industry developed, with an end-of-pipe treatment focus that aimed at cleaning up the combined wastewater prior to discharge Savelski and Bagajewicz [2].

Problems of high COD wastewater and associated high disposal costs to the local municipal treatment works were being encountered in a starch manufacturing plant that had been designed and commissioned in the 1950s and to which, over subsequent years, various treatment plants had been added to meet compliance with the developing local environmental regulations. At the start of the project to investigate the performance of the wastewater treatment train, factory management had the attitude that the solution to the problem would be the addition of appropriate plant to "clean up" the final effluent before discharge to the municipal sewer. Opportunities to reduce water use and waste generation through process modification and changes to plant operational procedures had not been seriously investigated. This paper presents the observations and results of an investigation into the performance of the wastewater treatment plant (WWTP).

\section{Plant description}

\subsection{Inputs and outputs for a wheat starch manufacturing processes}

With the basic inputs of wheat flour and water, after the processing stages outputs included a range of saleable products as well as unwanted by-products and three tailing streams. During the study, the starch manufacturer had an average flour throughput of $59 \mathrm{t} / \mathrm{d}$, an average freshwater usage of $8.6 \mathrm{~kL} / \mathrm{t}$ flour processed, and approximately $75 \%$ of input water was discharged to sewer Pidgeon et al. [3]. Inputs and outputs for the site studied are shown in Figure 1.

Outputs, for which no commercial market existed, included by-products such as gums, pentosans and fibre as well as three tailing streams. These tailing streams were named according to the equipment from which they were generated and ended with an ' $E$ ' to represent 'effluent' (as opposed to the concentrate stream from the separator). By-products were combined and trucked off-site to a farm where the composite was used as liquid fertiliser - at a trucking cost for the starch manufacturer. The remaining tailing streams (QXE, SB80E and SD4E) were treated through the on-site WWTP prior to sewer discharge. Factory shutdowns or operations at a reduced flour throughput were sometimes necessary while a backlog of effluent was treated and discharged, as well as during periods of effluent treatment plant failure and subsequent recovery. Spillage of effluent onto the processing floor area was not uncommon. WWTP processing outputs included an effluent stream, anaerobic sludge and biogas. The biogas was used in the boiler and offset costs associated with natural gas purchases. 


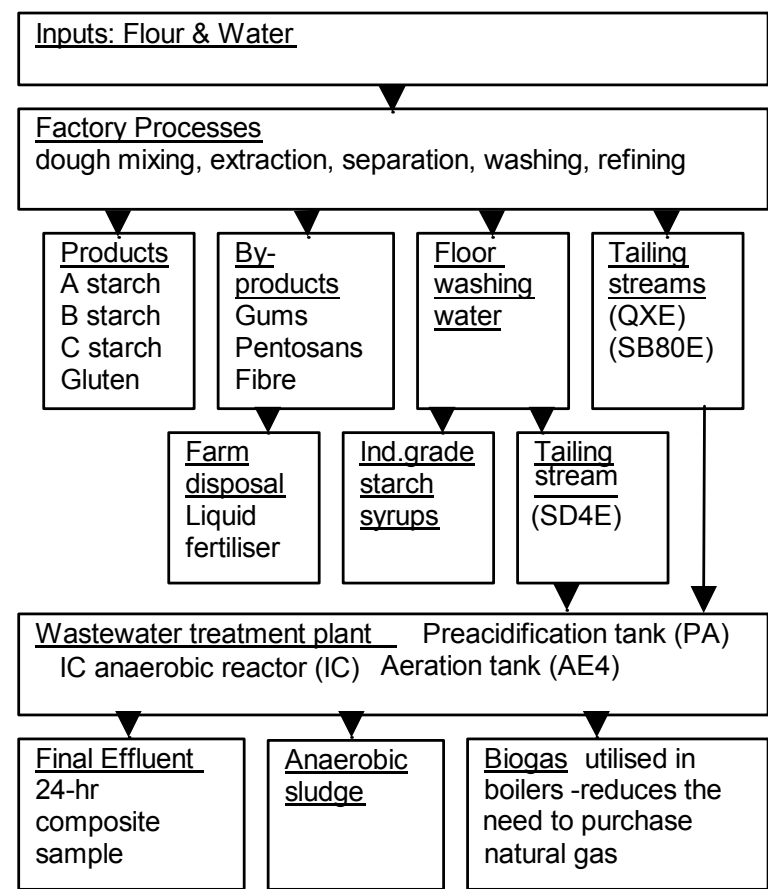

Figure 1: $\quad$ Inputs and outputs for a wheat starch manufacturer.

\subsection{Onsite wastewater treatment plant layout}

When the investigation commenced, the onsite WWTP, as shown in Figure 2 consisted of a pre-acidification (PA) head tank, the PA tank, a mixing tank (where the combined preacidified starch tailings were mixed with a portion of recycled anaerobic effluent), an internally circulating (IC) anaerobic reactor and an aeration tank. Although controlled through a PLC/MMI, in times of crisis field adjustments were possible.

The pre-acidification (PA) tank doubled as a buffer tank and received unacidified tailing streams from the starch factory. With a $120 \mathrm{~m}^{3}$ total capacity, it was designed to operate at less than $50 \%$ volume to provide an additional 4.5 hour 'calamity' capacity at a typical inflow of $13 \mathrm{~m}^{3} / \mathrm{h}$. During times of extraordinary production conditions the maximum throughput of the on-site treatment plant was $26 \mathrm{~m}^{3} / \mathrm{h}$. The feed rate set from the PA tank to the Mix Tank was equal to the effluent discharge rate to sewer Aquatec-Maxcon Pty Ltd [4].

During the investigation the WWTP continuously evolved. The aeration tank was taken off-line and replaced with a temporary tank. An EIMCO Delta-Stak ${ }^{\mathrm{TM}}$ Clarifier was then installed and the aeration process was eventually removed altogether. The WWTP and its processing streams were continuously altered and experimented upon, with the aim of improving final effluent quality. 


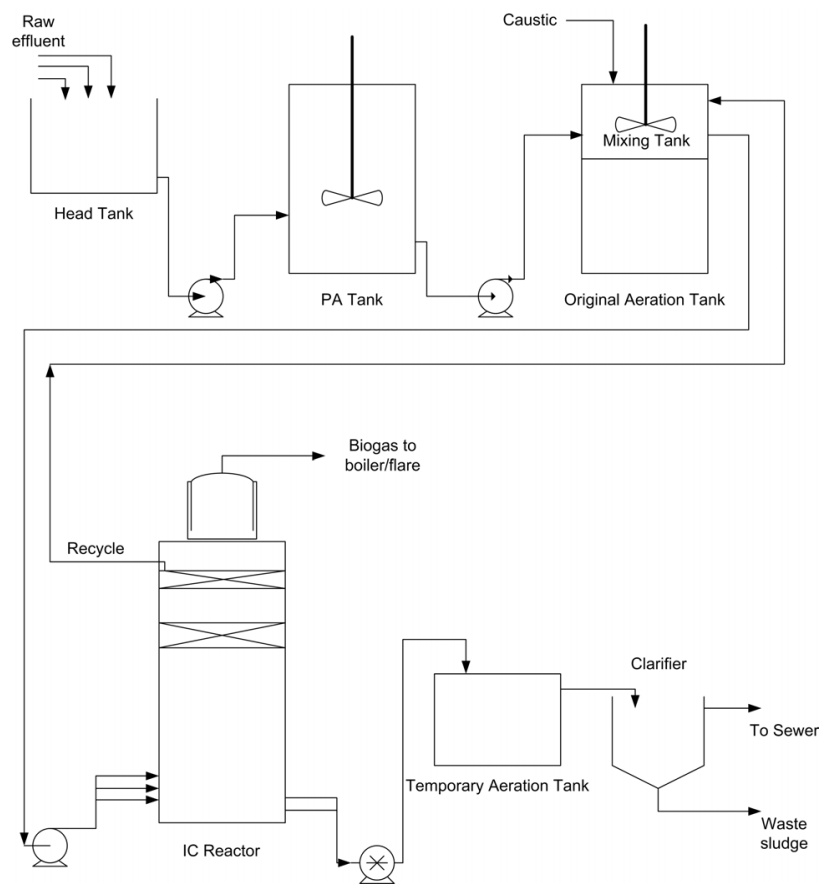

Figure 2: $\quad$ Main components of the wastewater treatment plant.

\subsection{Operation and maintenance of WWTP}

The most important process parameters for operating and maintaining an effective WWTP at this site, according to Moosbrugger [5] are listed in Table 1.

For the operation of the IC reactor, decreases in gas production concurrent with VFA increases are signs of imminent process failure; $5 \mathrm{meq} / \mathrm{L}$ of VFA in the reactor was the operational guideline. Alkalinity provides a buffer against $\mathrm{pH}$ changes and therefore $\mathrm{pH}$ is more stable at higher alkalinities. Causes of excessive granule loss include COD loading increase; toxic spills in factory; and changes to substrate feed, $\mathrm{pH}$, and temperature. The measurement of settleable solids was indicative of the situation in the IC reactor. Clarifier performance was dependent upon the solids settling rate EIMCO Process Equipment Company [6] and whilst reducing the solids in the final effluent, an unwanted sludge product was collected from the bottom of the cone and pumped to another sludge storage tank for later disposal.

\section{Materials and methods}

Background information was collected from the study site whilst also gaining practical experience in the day-to-day operations related to the starch factory and WWTP processes. In-house data, process flow sheets, performance reports and commissioning operational manuals were all reviewed. Research was undertaken that included the collection of WWTP process samples, sample analysis and data 
entry to continuously monitor performance trends. Personal communications with administrative and processing staff also assisted in gaining a deep understanding of the issue, including the realistic constraints for that particular site, wastewater generation practices, likely process inhibitors and wastewater by-products.

Table 1: $\quad$ Important process parameters for WWTP operation.

\begin{tabular}{|c|c|}
\hline Process Parameter & $\begin{array}{l}\text { Design capacity, optimal range and other } \\
\text { factors }\end{array}$ \\
\hline $\begin{array}{l}\text { COD-load to the IC } \\
\text { (Measured on unfiltered } \\
\text { sample from mix tank feed } \\
\text { (PA effluent)) }\end{array}$ & $\begin{array}{l}\text { - } 4.4 \text { tonnes (metric) COD per day } \\
\text { - } \quad \text { COD load }(\mathrm{t} / \mathrm{d})=\text { COD concentration } \\
{\left[\mathrm{kg} / \mathrm{m}^{3}\right]^{*} \text { mix tank feed flow }\left[\mathrm{m}^{3} / \mathrm{d}\right]}\end{array}$ \\
\hline $\mathrm{pH}$ in $\mathrm{IC}$ reactor & 6.8 to 7.2 optimal; Never $<6.5$ or $>7.5$ \\
\hline $\mathrm{pH}$ in mix tank & $\begin{array}{l}\mathrm{pH} \text { range } 6.0 \text { to } 6.2 \text { and adjusted to correct } \mathrm{IC} \\
\text { reactor } \mathrm{pH} \text { if needed. }\end{array}$ \\
\hline Mix tank temperature & $\begin{array}{l}36 \pm 2{ }^{\circ} \mathrm{C} \text { optimal } \\
30-40{ }^{\circ} \mathrm{C} \text { no serious impact on performance } \\
25-30{ }^{\circ} \mathrm{C} \text { anaerobic treatment efficiency } \\
\text { decreases } \\
>40{ }^{\circ} \mathrm{C} \text { damaging to anaerobic biomass }\end{array}$ \\
\hline VFA in IC reactor & Should not exceed $5 \mathrm{meq} / \mathrm{L}$ \\
\hline Alkalinity in IC reactor & Should be $>50 \mathrm{meq} / \mathrm{L}$. \\
\hline $\begin{array}{l}\text { Settleable solids in } \mathrm{IC} \\
\text { reactor effluent }\end{array}$ & $\begin{array}{l}1 \mathrm{~min}-\text { should not exceed } 1 \mathrm{~mL} \text { (measured } \\
\text { with Imhoff cone). }\end{array}$ \\
\hline $\begin{array}{l}\text { Suspended solids (SS) in } \\
\text { PA and IC effluent }\end{array}$ & $\begin{array}{l}\text { Used to assess changes in SS levels in the IC } \\
\text { reactor }\end{array}$ \\
\hline Gas production rate & $\begin{array}{l}\text { Important indicator for 'health' of anaerobic } \\
\text { reactor }\end{array}$ \\
\hline
\end{tabular}

All samples collected on site were analysed immediately according to appropriate standard methods. Samples were collected throughout the treatment train, including input streams (QXE, SD4E and SB80E), wastewater treatment effluent streams (PA, PA sediment, mix tank, IC and AE4) and final effluent stream (automatic sampler on magflow). Input streams and treatment processing streams were grab samples while the final effluent stream was a composite sample collected over a 24 hour period. Parameters tested included COD, pH, temperature, SS, total solids (\%), volatile fatty acids (VFA), alkalinity, $\mathrm{pH}$, temperature, SS, settleable solids (1 min and $60 \mathrm{~min}$ ), and feed and discharge rates $\left(\mathrm{m}^{3} / \mathrm{h}\right)$. All COD tests were COD total using a Merck COD testing kit and Solids (\%) was measured using a Sartorius moisture analyser. Operating parameters measured and/or calculated for the WWTP during the course of the study are assessed against the design capacity and optimal operating conditions for effective operation of the WWTP. 


\section{Results and discussion}

\subsection{Factory generated waste streams}

The measured characteristics of three tailing streams are shown in Table 2. QXE was a relatively dilute and oxygen depleted tailing stream containing a mixture of tailing and fractured B-starch particles, proteins, fats and water. With a flow rate of $12-14 \mathrm{~m}^{3} / \mathrm{h}$ this represented around $60 \%$ of the WWTP influent volume. If the QXE were to be subjected to advanced treatment such as membrane filtration to obtain the water for reuse, this would effectively increase the hydraulic retention time (HRT) and the solids retention time (SRT) of the other two streams. This would, in effect, increase the organic loading rate (OLR) capacity of the WWTP. The SB80E stream contained a large proportion of gums and pentosans while the SD4E stream was what remained following final scavenging of solid particles from the floor washing wastewater.

Table 2: Characteristics of tailing streams generated from wheat starch manufacturing process (mean values followed by range in parenthesis).

\begin{tabular}{|l|l|l|l|}
\hline Parameter & QXE & SB80E & SD4E \\
\hline $\begin{array}{l}\text { Flow rate range, } \\
\mathrm{kL} / \mathrm{h}\end{array}$ & $12-14$ & $4-6$ & $4-6$ \\
\hline Temperature $\left({ }^{\circ} \mathrm{C}\right)$ & $\begin{array}{l}\text { Mean 28.5 } \\
(23.8-32.6)\end{array}$ & $\begin{array}{l}\text { Mean 30.0 } \\
(25-34)\end{array}$ & $\begin{array}{l}\text { Mean 25.6 } \\
(22.7-28.1)\end{array}$ \\
\hline $\mathrm{pH}$ & $\begin{array}{l}\text { Mean 5.0 } \\
(3.73-6.11)\end{array}$ & $\begin{array}{l}\text { Mean 3.6 } \\
(3.48-3.87)\end{array}$ & $\begin{array}{l}\text { Mean 3.7 } \\
(3.38-4.16)\end{array}$ \\
\hline $\begin{array}{l}\text { COD Total } \\
(\mathrm{mg} / \mathrm{L})\end{array}$ & $\begin{array}{l}\text { Mean 12,020 } \\
(9720-15,300)\end{array}$ & $\begin{array}{l}\text { Mean 55,110 } \\
(22,120-99,800)\end{array}$ & $\begin{array}{l}\text { Mean 27,280 } \\
(23,040-33,800)\end{array}$ \\
\hline $\begin{array}{l}\text { Suspended Solids } \\
(\mathrm{SS})(\mathrm{mg} / \mathrm{L})\end{array}$ & $\begin{array}{l}\text { Mean 930 } \\
(610-2010)\end{array}$ & $\begin{array}{l}\text { Mean 44,840 } \\
(36,580-55,260)\end{array}$ & $\begin{array}{l}\text { Mean 11,600 } \\
(7770-15,480)\end{array}$ \\
\hline Solids $(\%)$ & $\begin{array}{l}\text { Mean 0.6 } \\
(0-6.4)\end{array}$ & $\begin{array}{l}\text { Mean 1.7 } \\
(0-6.4)\end{array}$ & $\begin{array}{l}\text { Mean 0.8 } \\
(0-1.82)\end{array}$ \\
\hline
\end{tabular}

\subsection{Operational parameters for the WWTP during the study}

Process parameters of importance to the effective operations of the WWTP were measured and data are presented in Table 3. By comparing the operational realities with the design or optimal operational values it becomes apparent that the IC reactor was regularly overloaded with organic matter, it was not always operating within the optimal $\mathrm{pH}$ range, temperature fluctuations occurred, alkalinity was often lower than recommended and settleable solids results indicate that biomass washout did occur. Any of the factors causing biomass loss could have been responsible as factors relating to organic overloading, substrate feed changes, $\mathrm{pH}$ changes, temperature changes and toxic spills to the factory floor were all known to occur during the study period.

The mean suspended solids levels in the PA and IC reactor were similar values demonstrating poor performance for the IC reactor in terms of SS 
reductions from the PA effluent. A high SS loading in the IC effluent was also an issue with respect to compliance with discharge requirements as outlined in Pidgeon et al. [3]. Given the excessive organic loading rate to the WWTP, the mean gas production rate of $45 \mathrm{~m}^{3} / \mathrm{h}$ was low averaging $0.22 \mathrm{~m}^{3} \mathrm{CH}_{4} / \mathrm{kg}$ COD removed. On days of moderate production (average flour throughput of $59 \mathrm{t} / \mathrm{d}$ ) and good wastewater analytical results the biogas production rate easily achieved around $80 \mathrm{~m}^{3} / \mathrm{h}$.

Table 3: $\quad$ Operating parameters measured at WWTP.

\begin{tabular}{|l|l|}
\hline Process Parameter & Operational values \\
\hline $\begin{array}{l}\text { COD-load to the IC } \\
(\text { tonnes COD/d) }\end{array}$ & $\begin{array}{l}\text { Mean } 6.9 \text { tonnes/d, Std Dev 2.7, range 0.8- } \\
23.3\end{array}$ \\
\hline $\mathrm{pH}$ in IC reactor & Mean 6.9, Std Dev 0.4, range 5.3-10.6 \\
\hline $\mathrm{pH}$ in mix tank & Mean 6.5, Std Dev 0.5, range 3.5-10.6 \\
\hline Mix tank temperature $\left({ }^{\circ} \mathrm{C}\right)$ & Mean 28.8, Std Dev 4.2, range 6.71-36.6 \\
\hline $\begin{array}{l}\text { VFA in IC reactor } \\
(\mathrm{meq} / \mathrm{L})\end{array}$ & Mean 15, Std Dev 20, range 0-134 \\
\hline $\begin{array}{l}\text { Alkalinity in IC reactor } \\
(\mathrm{meq} / \mathrm{L})\end{array}$ & Mean 38, Std Dev 15, range 0-112 \\
\hline $\begin{array}{l}\text { Settleable solids in IC effluent } \\
(\mathrm{mL})\end{array}$ & $\begin{array}{l}1 \text { min: Mean 0.3, Std Dev 0.5, range 0-2 } \\
60 \text { min: Mean 79, Std Dev 56, range 0.5-450 }\end{array}$ \\
\hline $\begin{array}{l}\text { SS in PA tank and IC effluent } \\
(\mathrm{mg} / \mathrm{L})\end{array}$ & $\begin{array}{l}\text { PA effluent: Mean 2825, Std Dev 2895, } \\
\text { range 0-22,970 } \\
\text { IC effluent: Mean 2700, Std Dev 1559, } \\
\text { range 384-13,260 }\end{array}$ \\
\hline Biogas production rate $\left(\mathrm{m}^{3} / \mathrm{h}\right)$ & \begin{tabular}{l} 
Mean 45, Std Dev 21, range 3.2-112 \\
\hline
\end{tabular} \\
\hline
\end{tabular}

The performance of the WWTP was usually measured as the amount of COD reduction achieved from the PA effluent to the IC effluent, expressed as a percentage. Over a monitoring period of 18 months, the average calculated reduction in COD concentration from the PA to the IC was 58\% (std dev $=17$ ). On average, the onsite WWTP discharged $430 \mathrm{~kL}$ of wastewater per day (range 323-3,264, standard deviation 198) with an average suspended solids (SS) concentration of $2,500 \mathrm{mg} / \mathrm{L}$ (range 610-11,700, standard deviation 1,568) and an average $\mathrm{BOD}_{5}$ of $1,950 \mathrm{mg} / \mathrm{L}$ (range 140-13,000, standard deviation 1,855).

\subsection{Wastewater generation practices and performance inhibitors}

Factors identified as having the potential to adversely affect treatment plant performance included factory shutdown maintenance and cleaning issues, hydraulic and organic overloading, accidental inputs of sulphur and human operating errors.

Maintenance of equipment during shutdown periods often involved the stripping down of equipment, repairing, reassembly and degreasing and/or regreasing. Sodium hypochlorite was also used as a cleaning agent throughout the factory following shutdown. Floor washing wastewater was collected in a sump 
and processed through the SD4 to scavenge solids. SD4E was then directed to the WWTP for treatment with the other processing streams. Sometimes this effluent stream had a strong odour of chlorine and/or solvents. Cleaner production principles and practices applied during maintenance events aimed at preventing these materials from entering into the floor washing wastewater would reduce inputs with reactor inhibitory consequences.

The IC anaerobic reactor was regularly overloaded in terms of organic and hydraulic inputs Pidgeon et al. [3]. It was designed to treat an average OLR of 4.4 tonne $\mathrm{COD} / \mathrm{d}$ and an average flow rate of $13 \mathrm{~m}^{3} / \mathrm{h}$, however it typically operated with an average COD loading of $6.9 \mathrm{t} / \mathrm{d}$ at a flow rate of $18-20 \mathrm{~m}^{3} / \mathrm{h}$. By-products included beneficial and non beneficial products, these being methane and anaerobic sludge respectively. The negative impact of COD overloading is enhanced when raw inputs to the reactor are insufficiently preacidified. Experiments treating wheat starch wastewater found that acidogenic fermentation of the raw starch stream prevented the growth of nuisance anaerobic bacteria that caused sludge bulking Endo and Tohya [7] and positively influenced granular sludge bed formation and stability in UASB reactors Moosbrugger [8].

High total sulphide levels (up to $31 \mathrm{mg} / \mathrm{L}$ ) were detected in samples of the final effluent discharged to sewer during the third and fourth months of monitoring while the PA tank sample had a zero value indicating that inputs of sulphur were occurring within the treatment train. Total sulphide $\left(\mathrm{S}^{2-}\right)$ had a maximum guideline of $5 \mathrm{mg} / \mathrm{L}$ in the Trade Waste Guide Industrial Liquid Waste Sewer Acceptance Criteria as it can cause corrosion and generate odours and gases in sewers, potentially compromising safety Brisbane Water [9]. Sulphide is also known to inhibit methane generation Metcalf and Eddy [10] due to the fact that sulphidogens and methanogens have physiological similarities and operate under similar optimum temperature and $\mathrm{pH}$ conditions Zhou and Fang [11]. According to Randall [12] sulphides are one of the contaminants typically present in spent caustic liquors that have been used to strip acidic components from gas streams. It was concluded that a spent caustic solution obtained from a local gas company, for stream $\mathrm{pH}$ adjustment purposes, was the most probable source of sulphur inputs. Following this discovery only new $\mathrm{NaOH}$ was used for $\mathrm{pH}$ adjustment purposes and the problem soon disappeared. However, corrosion had already rendered the aeration tank as unsuitable for use due to a combination of operating conditions within the WWTP, including the presence of sulphur, a low operating $\mathrm{pH}$ in the $\mathrm{IC}$ reactor and final aeration of the waste stream prior to discharge.

A human operating error which occurred late in the seventh month of testing caused the IC anaerobic reactor to be dosed with an excessive amount of $\mathrm{NaOH}$ and subsequently fail. A check on the PLC showed that the $\mathrm{pH}$ 'high' level setting had been altered to $\mathrm{pH}=10$ during the evening. Although believed to be an accident, this uninformed change by some unknown person caused an immediate shutdown for production. The program did not include a register of persons logging onto or off the PLC system. It was a costly exercise to dispose of the highly alkaline waste in the reactor as well as the issue of re-establishing 
new biomass within the reactor. Upon start-up, production could only occur at a reduced rate to enable the biological activity within the reactor to increase progressively towards steady state conditions. As a consequence of this reactor failure, $\mathrm{Mg}(\mathrm{OH})_{2}$ was used for $\mathrm{pH}$ adjustments following that time. A more secure and accountable computer program log-in was also set up to ensure that only those authorised could gain access to areas where process parameter set points were altered.

Good housekeeping practices using a cleaner production approach, the implementation of systems that minimise human errors and ensuring inputs do not contain inhibitory substances should enhance the performance of the WTTP studied.

\section{Conclusions}

Factors were identified as having the potential to adversely affect the WWTP operations and performance, these being overloading, housekeeping issues during maintenance and cleaning events, accidental inputs of inhibitory substances such as sulphur compounds in a spent caustic stream, and human errors. Preventing inhibitory substances from entering into the floor washing wastewater ensures that they are not in the SD4E stream that is input to the PA head tank. Human errors were addressed by increasing security measures where the settings could be changed on the PLC as well as changing to a less toxic compound being used for $\mathrm{pH}$ adjustment purposes.

The IC reactor was not always operated at recommended $\mathrm{pH}$ levels or with sufficient alkalinity to protect the sludge against shock associated with sudden changes. Operation at a $\mathrm{pH}$ less than the optimal range probably contributed to a reduction in methane generation and caused the formation of $\mathrm{H}_{2} \mathrm{~S}$, which upon aeration is oxidised to sulphuric acid, and ultimately corroded the aeration tank. Alkalinity ties in with $\mathrm{pH}$ as it provides the stream with a buffering capacity against sudden $\mathrm{pH}$ changes. The unstable $\mathrm{pH}$ recorded during the study would, in part, be a symptom of operating at a lower than recommended alkalinity. Operation of the WWTP according to optimal $\mathrm{pH}$ and alkalinity values would increase biological activity causing an increase in methane generation, reduce the incidence of washout and ensure that $\mathrm{H}_{2} \mathrm{~S}$ does not dominate.

Washout of biomass did occur for the plant with factors such as organic overloading, sudden changes to $\mathrm{pH}$ and toxic inputs from floor washing water or other sources thought to be responsible. WWTP performance was generally poor with biogas generation averaging $45 \mathrm{~m}^{3} / \mathrm{h}$ despite heavy organic loadings. The average calculated reduction in COD from the PA to the IC stages was $58 \%$.

Enhancing the performance of this WWTP treating wheat starch factory tailings requires that the system be operated at optimal conditions for the biological component to optimally treat the waste inputs. Should the QXE stream that represents $60 \%$ of the WWTP influent be polished for reuse within the factory process this in turn would increase the HRT and SRT of the other streams treated through the WWTP. Water extracted for reuse prior to entry to the WWTP would result in less fresh water being required. As well as reducing overall water usage in the starch factory, this would simultaneously reduce the 
hydraulic flow rate to the WWTP. Effectively this would increase the OLR of the WWTP - perhaps even to the point where a portion of liquid fertilizer could be treated through the WWTP thereby saving trucking costs and converting more solids to methane for beneficial on-site use.

\section{Acknowledgements}

Funding and assistance in kind for this project were provided by Weston Bioproducts, a Division of George Weston Foods Limited, Australia. One of the authors (EFP) was supported by a scholarship from Weston Bioproducts during the course of this study.

\section{References}

[1] Unnikrishnan, S. and D.S. Hegde, An analysis of cleaner production and its impact on health hazards in the workplace. Environment International, 32(1), p. 87-94, 2006.

[2] Savelski, M. and M. Bagajewicz, On the optimality conditions of water utilization systems in process plants with single contaminants. Chemical Engineering Science, 55, p. 5035-5048, 2000.

[3] Pidgeon, E., J.N. Ness, and J.A. Scott. The application of membrane filtration technology for a wheat starch processing industry. in National Environment Conference. Brisbane, 2003.

[4] Aquatec-Maxcon Pty Ltd, Love Starches Pty Ltd - Moorooka Site IC Reactor Trade Waste Plant Operating \& Control Philosophy, AquatecMaxcon Pty Ltd, Brisbane, p. 1-6, 1996.

[5] Moosbrugger, R., IC reactor COD overload protection \& operating instructions, unknown, Brisbane, p. 1-7, 1997.

[6] EIMCO Process Equipment Company, EIMCO Delta-Stak Clarifier Operating Instructions, Salt Lake City, Utah, 1999.

[7] Endo, G. and Y. Tohya, Ecological study of anaerobic sludge bulking caused by filamentous bacterial growth in an anaerobic contact process. Water Science and Technology, 20(11/12), p. 205-211, 1988.

[8] Moosbrugger, R.E. Single and two stage UASB systems: preacidification and sludge granulation. in 8th IAWQ International Conference on Anaerobic Digestion. Sendai, Japan: IWA Publishing, 1997.

[9] Brisbane Water, The Trade Waste Guide: Protecting our waterways and Moreton Bay, Brisbane City Council, Brisbane, p. 1-16, 1999.

[10] Metcalf \& Eddy, Wastewater Engineering Treatment and Reuse, Metcalf \& Eddy, International Edition. fourth ed, ed. G. Tchobanoglous, F.L. Burton, and H.D. Stensel. Sydney: McGraw-Hill, 2003.

[11] Zhou, G.-M. and H.H.P. Fang, Competition between methanogenesis and sulfidogenesis in anaerobic wastewater treatment. Water Science and Technology, 38(8-9), p. 317-324, 1998.

[12] Randall, T.L. Case studies on caustic sulfide wastewater wet oxidation treatment in Hazardous \& Industrial Wastes, 26th Mid Atlantic Industrial Waste Conference. Newark, DE: Technomic, 1994. 